\title{
PEMBERIAN SARI KACANG HIJAU UNTUK MEMPERLANCAR ASI DI BPM HJ.DINCE SAFRINA, S.ST PEKANBARU
}

\author{
Rita afni, SST, M.Kes ${ }^{(1)}$, Risa Pitriani, SST, M.Kes ${ }^{(2)}$ \\ STIKes Hang Tuah Pekanbaru \\ Email: rita.afni@htp.ac.id
}

\begin{abstract}
The most suitable food for babies is breast milk (ASI), because breast milk is intended for babies as a staple food for babies that contains complete nutrition for babies and various anti-body substances so that they will rarely get sick. So it is hoped that mothers can provide exclusive breastfeeding to their babies without exception, whatever the obstacles should not be used as a reason for a mother to provide complementary foods or formula milk to her baby until the baby is 6 months old (Anggraini, 2010). This service activity was carried out at BPM Hj. Dince Safrina, S.ST, M.kes Kec. Coastal Rumbai of Pekanbaru City. This community service method is carried out in the form of counseling, after completing the delivery of the material, the speaker demonstrates how to process green bean juice in front of the participants and the speaker opens a question and answer session, participants understand the material, by asking questions to the presenter, this community service is going well and as planned. The results of this activity were obtained by the participants to understand and understand about the benefits of green beans to facilitate breastfeeding and will regularly consume green bean juice.
\end{abstract}

Keywords: Mung bean juice, breast milk, breastfeeding mothers

\begin{abstract}
ABSTRAK
Makanan yang paling sesuai untuk bayi adalah Air Susu Ibu (ASI), karena ASI memang diperuntukkan bagi bayi sebagai makanan pokok bayi yang mengandung nutrisi lengkap untuk bayi serta berbagai zat anti body sehingga akan jarang sakit. Maka diharapkan para ibu dapat memberikan ASI Eksklusif kepada bayinya tanpa terkecuali, apapun kendalanya tidak boleh dijadikan alasan seorang ibu memberikan makanan pendamping atau susu formula kepada bayinya sampai usia bayi 6 bulan (Anggraini, 2010). Kegiatan pengabdian ini dilaksanakan di BPM Hj.Dince Safrina, S.ST, M.kes Kec. Rumbai Pesisir Kota Pekanbaru. Metode pengabdian masyarakat ini dilaksanakan dalam bentuk penyuluhan, setelah selesai penyampaian materi tersebut, pemateri mendemostrasikan cara pengolahan sari kacang hijau di depan peserta dan pemateri membuka sesi tanya jawab, peserta memahami materi, dengan mengajukan pertanyaan kepada penyaji, pengabdian pada masyarakat ini berjalan dengan baik dan sesuai rencana. Hasil kegiatan ini didapatkan para peserta memahami dan mengerti tentang manfaat kacang hijau untuk memperlancar ASI dan akan rutin mengkonsumsi sari kacang hijau.
\end{abstract}

\section{Kata Kunci: Sari Kacang Hijau, ASI, Ibu Menyusui}




\section{PENDAHULUAN}

Makanan yang paling sesuai untuk bayi adalah Air Susu Ibu (ASI), karena ASI memang diperuntukkan bagi bayi sebagai makanan pokok bayi yang mengandung nutrisi lengkap untuk bayi serta berbagai zat anti body sehingga akan jarang sakit. Maka diharapkan para ibu dapat memberikan ASI Eksklusif kepada bayinya tanpa terkecuali, apapun kendalanya tidak boleh dijadikan alasan seorang ibu memberikan makanan pendamping atau susu formula kepada bayinya sampai usia bayi 6 bulan (Anggraini, 2010).

\section{Cakupan pemberian ASI}

Eksklusif pada bayi di indonesia menurut profil kesehatan Indonesia tahun 2018 mengalami kenaikan sebesar $65,16 \%$ dibandingkan tahun 2017 yaitu 61,33\%. Angka tersebut sudah melampaui target Renstra tahun 2017 yaitu 44\%. Persentase tertinggi cakupan pemberian ASI Eksklusif terdapat pada Nusa Tenggara Barat 87,35\%, sedangkan persentase terendah terdapat pada Papua 15,32\%. Tepatnya persentase di Provinsi Riau yaitu 57,65 \%. Ada lima provinsi yang belum mencapai target Renstra tahun 2017 yaitu Sulawesi Utara, Banten, Maluku, Papua Barat, Papua (Kemenkes, 2017). Namun Indonesia masih berada diperingkat 49 dari 51 neraga yang mendukung pemberian ASI Eksklusif berdasarkan data World Breastfeeding Trends Initiative (WBTi) tahun 2012 (Nugroho, 2013).

Berdasarkan hasil penelitian yang dilakukan (Siagian and Yusmaharani, 2019) dengan judul hubungan pengetahuan dan sikap tentang Air Susu Ibu perah (ASIP) terhadap ASI Eksklusif di Kota Pekanbaru tahun 2018 didapatkan data ibu yang memiliki pengetahuan tinggi dan memberikan ASI Eksklusif sebanyak $63 \%$, pengetahuan rendah dan tidak memberikan ASI Eksklusif 59,1\%.

Makanan termasuk kedalam hal utama yang sangat berpengaruh terhadap produksi ASI, Karena apabila makanan yang ibu makan cukup akan gizi dan pola makan yang teratur, maka produksi ASI akan berjalan dengan lancar (Mulyani, 2013). Kebutuhan nutrisi ibu menyusui lebih banyak dari pada ibu hamil, karena nutisi tersebut diperlukan untuk produksi ASI dan memulihkan kesehatan ibu. Tambahan kebutuhan ibu menyusui yaitu Kalori (Energy) 500-800 kal, Protein 25 gr, Besi ( $\mathrm{Fe}$ ) $15 \mathrm{mg}$, Kalsium (Ca) 25 mg, Retinol (Vit A) 30 gr, Vitamin C (Vit C) $25 \mathrm{mg}$, Vit B12 $25 \mathrm{gr}$, Asam folat 15 gr (Purwitasari and Maryanti, 2009). Upaya yang dilakukan tenaga kesehatan agar ibu mendapatkan pengetahuan tentang cara yang tepat untuk dapat memperlancar pengeluaran ASI yaitu salah satunya dengan mengkonsumsi sari 
kacang hijau yang dapat membantu untuk proses pengeluaran ASI dan memberikan pengertian tentang pentingnya ASI Eksklusif untuk bayi (Badriah, 2011).

Sari kacang hijau mengandung Kalori (Energy) 109 kal, Protein 8.7 gr, Besi (Fe) $1.5 \mathrm{mg}$, Kalsium (Ca) 95 mg, Vitamin C (Vit C) $3 \mathrm{mg}$ (Marudut, 2018).

Data komposisi didalam kandungan masing-masing makanan yang dapat mempengaruhi produksi ASI memiliki khas masing-masing ada yang tinggi kandungannya ada yang rendah, tetapi untuk Kalori dan Protein yang terkandung didalam kacang hijau lebih tinggi dibandingkan makanan yang lainnya.

Berdasarkan hasil penelitian yang dilakukan Ma'rufah, dkk (2017) dengan judul Pengaruh Sari Kacang Hijau (Phaseolus Aureus) Terhadap Peningkatan Produksi Air Susu Ibu (ASI) Di Wilayah Puskesmas Bawen Kabupaten Semarang pada bulan Agustus 2017, Sari Kacang Hijau diberikan sebanyak $300 \mathrm{ml} 2$ kali perhari selama 8 hari menunjukkan produksi ASI setelah diberikan sari kacang hijau (Phaseolus Aureus) mengalami peningkatan rata-rata sebesar $63,63 \mathrm{cc}$ perhari.

\section{METODE KEGIATAN}

Metode pengabdian masyarakat ini dilaksanakan dalam bentuk penyuluhan dengan mengangkat tema "Pemberian Sari Kacang Hijau untuk memperlancar ASI di BPM Dince Safrina Pekanbaru" Setelah selesai penyampaian materi tersebut, pemateri mendemostrasikan cara pengolahan sari kacang hijau di depan peserta dan pemateri membuka sesi tanya jawab, peserta memahami materi, dengan mengajukan pertanyaan kepada penyaji.

\section{HASIL DAN PEMBAHASAN}

\section{Hasil Pelaksanaan Kegiatan}

Kegiatan yang dilakukan dalam penyuluhan ini dilaksanakan dalam beberapa tahap yang diawali dengan penyampaian materi terlebih dahulu, kemudian setelah diberikan materi melakukan demonstrasi dan seksi tanya jawab serta diskusi. Kegiatan penyuluhan ini dilaksanakan pada hari Senin tanggal 13 Mei 2019 bertempat di BPM Hj.Dince Safrina, S.ST, M.kes Kec. Rumbai Pesisir Kota Pekanbaru. Kegiatan ini memberikan hasil sebagai berikut :

1. Kelompok Penyaji

Berdasarkan hasil penyuluhan di BPM Hj.Dince Safrina, S.ST, M.kes Kec. Rumbai Pesisir Kota Pekanbaru, sudah terlihat bahwa kelompok penyaji mampu memberi sosialisasi mengenai pemberian sari kacang hijau pada ibu menyusui untuk memperlancar ASI. 


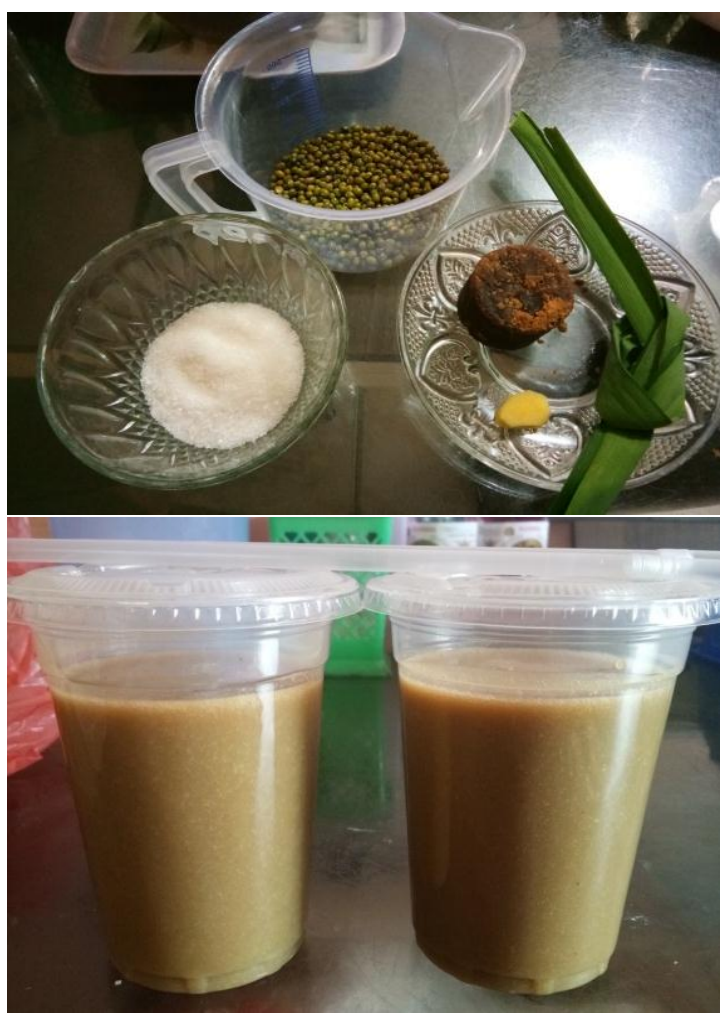

2. Pengunjung/Peserta pengabdian

a. Memahami materi yang disampaikan oleh pemateri.

b. Pengunjung yang hadir antusias dalam mengikuti penyuluhan.

c. Terjadi diskusi antara penyaji dan pengunjung.

d. Memahami materi penyuluhan tentang "Pemberian Sari Kacang Hijau pada Ibu Menyusui untuk memperlancar ASI' yang disampaikan oleh pemateri

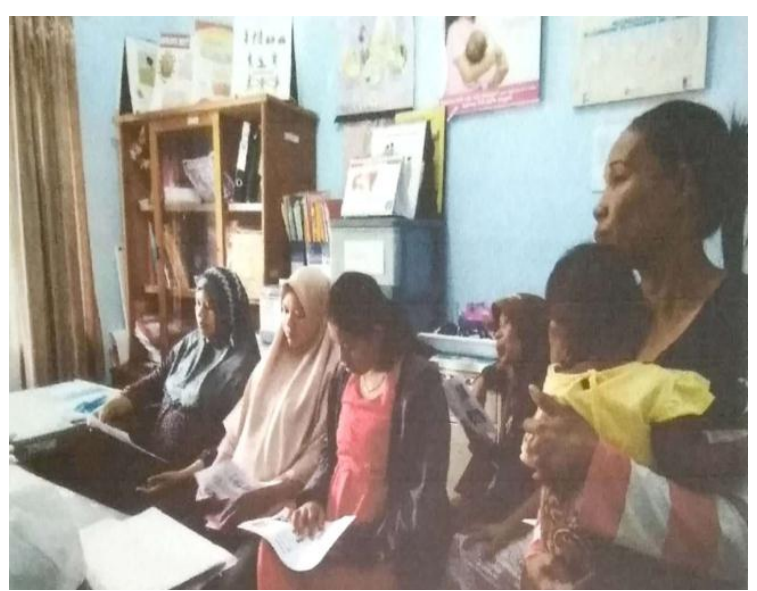

\section{Pembahasan}

Kegiatan penyuluhan tentang tentang "Pemberian Sari Kacang Hijau untuk memperlancar ASI' yang dilaksanakan di BPM Dince Safrina berjalan dengan baik dan sesuai rencana. Hal ini terbukti antusiasme para peserta saat mengikuti jalannya kegiatan. Para peserta penyuluhan benar-benar memperhatikan dan mendengarkan dengan baik penyuluhan yang disampaikan

\section{KESIMPULAN}

Kegiatan penyuluhan tentang Pemberian Sari Kacang Hijau Pada Untuk Memperlancar ASI di BPM Hj.Dince Safrina, S.ST, M.kes Kec. Rumbai Pesisir Kota Pekanbaru berjalan dengan baik dan sesuai rencana. Hal ini terbukti dari antusiasme para Pengunjung saat penyuluhan berlangsung.

Para peserta penyuluhan benarbenar memperhatikan dan mendengarkan dengan baik tentang materi yang 
disampaikan. Saat membuka seksi tanya jawab peserta sangat antusias untuk menjawab maupun bertanya

\section{DAFTAR PUSTAKA}

Anggraini, Y. (2010) Asuhan Kebidanan Pada Ibu Nifas. Edited by $\mathrm{T}$. Endroko. Yogyakarta: Pustaka Rihama.

Maritalia, D. (2017) Asuhan Kebidanan Pada Ibu Nifas. Edited by S. Riyadi. Yogyakarta: Gosyen Publishing.

Purwitasari, D. and Maryanti, D. (2009) Gizi Dalam Kesehatan Reproduksi.Edited by A.Setiawan. Yogyakarta: Nuha Medika.
Walyani, E. S. and Purwoastuti, E. (2015) Asuhan Kebidanan Masa Nifas Dan Menyusui. Yogyakarta: Pustakabarupress.

Widyastusi, K. (2014) 'Pengaruh Konsumsi Sari Kacang Hijau Terhadap ProduksiAir Susu Ibu (ASI) Pada Ibu Menyusui Di Wilayah Kerja PuskesmasDinoyo Malang'. Malang, p. xii.

Wulandari, D. T. and Jannah, S. R. (2015) 'Pengaruh Pemberian Sari Kacang Hijau Pada Ibu Nifas Dengan Kelancaran Produksi ASI', 5(2), pp 148153. 